\title{
LATVIJAS UNIVERSITĀTES FIZIKAS UN MATEMĀTIKAS FAKULTĀTES SĀKUMS
}

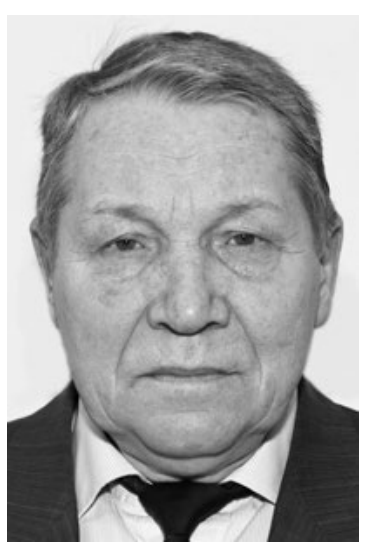

Jānis Jansons dzimis Jūrmalā (1944). Beidzis Rīgas 2. vidusskolu (1962) un kā fiziḳis Latvijas Valsts universitātes Fizikas un matemātikas fakultāti (1973). Studijās bija pārtraukums sakarā ar dienestu armijā. Līdztekus mācībām vakara nodaḷā strādājis turpat universitātē Pusvadītāju fizikas problēmu laboratorijā par laborantu, inženieri, vecāko inženieri (no 1962). Strādā Latvijas Universitātes Cietvielu fizikas institūtā par pētnieku (no 1978). Ieguvis maǵistra grādu fizikā (1994). Piešķirts Latvijas Zinātṇu akadēmijas goda doktora grāds fizikā (2014). 5 grāmatu, 119 zinātnisko publikāciju un 5 patentu autors.

Raksturvārdi: fizika, matemātika, universitāte, fakultāte, institūts.

\section{Ievads}

Latvijas Universitātes (LU) Fizikas un matemātikas fakultāte (FMF) sākta izveidot Latvijas pirmās padomju okupācijas laikā 1940./41. mācību gadā, sadalot divās daḷās Matemātikas un dabas zinātṇu fakultāti (MDZF). Sākoties pēc gada vācu nacistu okupācijai, 1941. gada 1. jūlijā sasauktā universitātes Padomes ārkārtas sēde nolēma atjaunot pirmspadomju laika LU Satversmi, struktūru un darbības kārtību. Tikai pēc atkārtotās padomju okupācijas Otrā pasaules kara beigās 1944. gada rudenī tika atjaunota FMF. No tā laika 80 gadus LU sastāvā ir FMF (tagad - Fizikas, matemātikas un optometrijas fakultāte).

Rakstā apskatīta fizikas un matemātikas studiju priekšvēsture, FMF dibināšana pirmās padomju okupācijas laikā 1940./41. mācību gadā, pārvērtības vācu nacistu okupācijas laikā un FMF attīstība līdz 1958. gadam otrās padomju okupācijas laikā.

\section{Priekšvēsture}

Vecajā Rīgas Politehniskajā institūtā, kas bija dibināts 1862. gadā, fizika un matemātika bija tikai mācību priekšmeti. Studenti nevarēja specializēties šajos priekšmetos, lai iegūtu akadēmisko grādu. Kas gribēja studēt šīs zinātnes, tiem vajadzēja doties uz Tērbatas Universitāti vai vēl tālāk - uz Pēterpils, Maskavas vai ārzemju augstskolām.

Pēc LU dibināšanas 1919. gada 28. septembrī fiziku un matemātiku varēja sākt studēt MDZF Matemātikas nodaļā un iegūt matemātikas zinātṇu kandidāta grādu, ko 1939. gadā pārdēvēja par maǵistra grādu. LU MDZF Matemātikas nodaḷā studenti varēja specializēties matemātikā, fizikā, geofizikā un astronomijā. Sākumā izmantoja mācību priekšmetu sistēmu, kaut gan formāli - kursu sistēmu. Tas bija tamdēḷ, ka daudzi studenti nevarēja iekḷauties studijām paredzētajos četros gados, jo līdztekus studijām bija spiesti strādāt materiālu apstākḷu dẹl.

Lai studenti varētu izstrādāt beigšanas zinātnisko darbu, matemātiķi izveidoja Matemātikas kabinetu, ko 1926. gadā pārdēvēja par Matemātikas semināru. To dibināja un vadijja prof. E. Lejnieks lìdz 1935. gadam, kad viņš aizgāja mūžǐbā. Pēc tam semināra vadību pārzināja fakultātes dekāns. Ar 1939. gadu semināru sāka vadīt vec. doc. A. Lūsis. Seminārā izstrādātas vismaz 20 zinātniskās publikācijas 


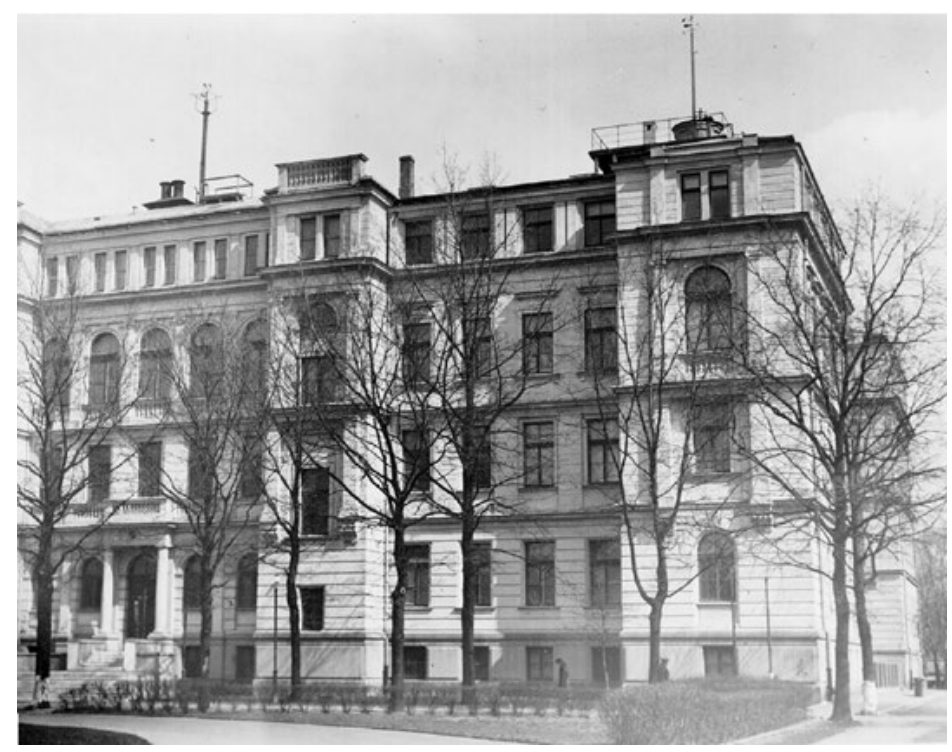

1. attēls. LU Laboratoriju ēka, kuras priekšpuses labajā spārnā izvietojās Fizikas institūts. No 1950. līdz 1958. gadam šeit atradās Fizikas un matemātikas fakultāte

un 4 mācību grāmatas akadēmisko kursu apjomā.

Fizikas padziļinātai apgūšanai doc. F. Gulbis jau 1919. gadā nodibināja Fizikas institūtu, kas darbojās līdz 1944. gadam LU Laboratoriju ēkā Kronvalda bulvārī 4 tās priekšpuses labajā spārnā (1. attēls). Tajā fizikas studenti izstrādāja maǵistra darbus, kā arī zinātnieki veica pētījumus. Tika izstrādāti kādi 25 darbi, pamatā optiskajā atomu spektroskopijā, fizikālajā ķīmijā, teorētiskajā fizikā un lietišķajā fizikā. F. Gulbis sarakstīja grāmatu Eksperimentālā fizika trīs sējumos, ko laida klajā no 1922. līdz 1929. gadam. Tā aptvēra visu akadēmiskās fizikas kursu. Pārstrādātu un papildinātu mācību grāmatu Fizika prof. F. Gulbis sarakstija Otrā pasaules kara laikā, bet paspēja izdot tikai tās pirmo sējumu 1943. gadā.

1921. gadā no Fizikas institūta nodalìjās Ģeofizikas un meteorologijas institūts, ko vadīja prof. R. Meijers, bet pēc viņa repatriācijas uz Vāciju 1939. gada rudenī institūta vadību pārṇēma prof. L. Slaucītājs. Institūta darbinieki publicējuši apmēram 40 pētījumus.

Teorētiskās astronomijas un analītiskās mehānikas institūtu (7. attēls) 1925. gadā nodibināja prof. A. Kloze. No 1936. gada par institūta direktoru kḷuva E. Gēliņš. Zinātnisko darbu publicēšanai institūts, sākot ar 1926./27. mācību gadu, izdeva Teorētiskās astronomijas un analìtiskās mehānikas institūta rakstus. Iznākuši vismaz trīs sējumi.

1921. gada septembrī nodibināja astronomisko kabinetu LU galvenajā ēkā, saṇemot savā rīcībā refraktora torni, auditoriju un divas nelielas istabas. 1922. gada 18. oktobrī kabinetu pārdēvēja par LU Astronomisko observatoriju (6. attēls). To no dibināšanas līdz 1944. gadam vadija vec. doc. A. Žaggers. Pie observatorijas tūdal izveidoja arī Laika staciju. Savus darbus observatorija publicēja $L U O b$ servatorijas rakstos, sākot ar 1932. gadu.

Matemātikas zinātṇu doktora grādu aizstāvēja un piešḳīra: R. Putniņam (1926), prof. E. Lejniekam (1929, goda doktora grādu), A. Lūsim (1938) un prof. A. Mēderam (1938, goda doktora grādu), doc. L. Slaucītājam (1942), doc. E. Fogelim (1943), doc. E. Grinbergam (1943), doc. R. Siksnam (1943) un prof. A. Žaggeram (1943).

30. gadu otrajā pusē, kad Latvijā dzīves līmenis strauji uzlabojās, LU sāka pāriet arī praktiski no mācību priekšmetu uz kursa sistēmas stingrāku ievērošanu. Tamdēl tika izstrā- 
1. tabula. Studentu maiṇa Matemātikas nodal̦ā

\begin{tabular}{ccccc}
\hline Mācibu gadi & Uzṇemtie & Studējušie & Beigušie & Kopā beigušie \\
\hline $1919 . / 20$. & 28 & 28 & - & - \\
\hline $1920 . / 21$. & - & 58 & - & - \\
\hline $1921 . / 22$. & 35 & 106 & - & $\mathbf{1}$ \\
\hline $1922 . / 23$. & 15 & 128 & 1 & $\mathbf{2}$ \\
\hline $1923 . / 24$. & 63 & 196 & 1 & $\mathbf{4}$ \\
\hline $1924 . / 25$. & 61 & 262 & 2 & $\mathbf{9}$ \\
\hline $1925 . / 26$. & 70 & 296 & 5 & $\mathbf{1 3}$ \\
\hline $1926 . / 27$. & - & 294 & 4 & $\mathbf{2 5}$ \\
\hline $1927 . / 28$. & 60 & 319 & 9 & $\mathbf{3 2}$ \\
\hline $1928 . / 29$. & 75 & 352 & 3 & $\mathbf{4 4}$ \\
\hline $1929 . / 30$. & 67 & 376 & 7 & $\mathbf{6 2}$ \\
\hline $1930 . / 31$. & 68 & 377 & 12 & $\mathbf{8 3}$ \\
\hline $1931 . / 32$. & 38 & 351 & 18 & $\mathbf{1 0 1}$ \\
\hline $1932 . / 33$. & 56 & 351 & 21 & $\mathbf{1 2 4}$ \\
\hline $1933 . / 34$. & 70 & 316 & 18 & $\mathbf{1 4 6}$ \\
\hline $1934 . / 35$. & 41 & 270 & 23 & $\mathbf{1 6 6}$ \\
\hline $1935 . / 36$. & - & 229 & 22 & $\mathbf{1 7 9}$ \\
\hline $1936 . / 37$. & 57 & 214 & 20 & 13 \\
\hline $1937 . / 38$. & 55 & 211 & 32 & \\
\hline $1938 . / 39$. & 46 & 243 & & 2 \\
\hline
\end{tabular}

dāti un 1939. gadā apstiprināti loti izsmeḷoši LU MDZF noteikumi par studijām un mācības plāniem. Tajos bija paredzēts, ka studijas katrā nozarojumā, ieskaitot akadēmiskos gala pārbaudījumus un darbu akadēmiskā grāda iegūšanai, ir četrgadīgas (8 semestri). Tās sadalītas divās daḷās: A - propedeitiskais posms un B - speciālais posms.

Līdz 1939. gadam Matemātikas nodaḷu bija beiguši 211 absolventi. Dati pa gadiem ir apkopoti 1. tabulā. 1920./21., 1926./27. un 1935./36. mācību gadā neuzṇēma studentus, jo vidusskolās nebija izlaidumi sakarā ar skolas mācību gadu skaita palielināšanu.

\section{Fizikas un matemātikas fakultātes dibi- nāšana Latvijas pirmās padomju okupā- cijas laikā (1940-1941)}

PSRS Sarkanā armija 1940. gada 17. jūnijā okupēja Latvijas Republiku un iedibināja pa- domju varu visos pārvaldes līmenos. Latvijas Valsts universitātes (LVU, tā padomju laikā tika pārdēvēta LU) rektora vietas izpildītājs (v. i.). J. Paškevics 1940. gada 13. septembrī nosūtīja vēstuli izglîtỉbas tautas komisāram ar priekšlikumu par MDZF sadalīšanu divās dạ̄ās: a) Fizikas un matemātikas un b) Dabas zinātṇu fakultātē, kas saskaņotos ar jaunajiem mācību plāniem. 16. septembrī komisariāts sadalǐšanu atḷāva.

Fizikas un matemātikas fakultātē izveidoja šādu struktūru:

1) katedras ar laboratorijām - 1: Fizikas;

2) katedras ar kabinetiem - 3: Matemātikas un mehānikas, G̦eofizikas un meteorologiijas, Astronomijas;

3) zinātniski pētnieciskās iestādes - 3: Fizikas institūts, Matemātikas un mehānikas institūts, Astronomiskā observatorija.

Par FMF dekānu norīkoja ārk. prof. F. Gulbi (2. attēls), par dekāna vietnieku - prof. 


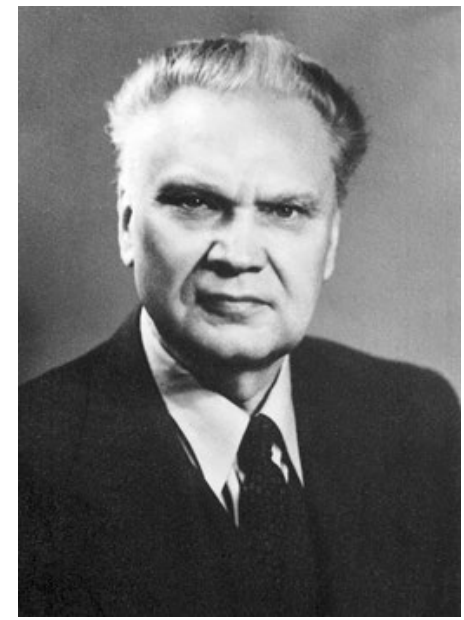

2. attēls. Fizikas un matemātikas fakultātes pirmais dekāns ārk. prof. Fricis Gulbis (no 1940. gada 1. oktobra lïdz 1941. gada 15. februārim)

A. Lūsi, par mācību darba pārzini - prof. E. Gēliṇu, par dekāna palīgu administratīvi saimnieciskās lietās - doc. J. Fridrichsonu (no novembra viṇa vietā iecēla doc. v. i. L. Jansonu). Apstiprināja šādu fakultātes Padomi:

1) dekāns ārk. prof. F. Gulbis (no 15.02.1941. doc. P. Ēks);

2) dekāna vietn. matemātikas prof. A. Lūsis;

3) mācību darba pārzinis astronomijas prof. E. Gēliņš;

4) dekāna palīgs administratīvi saimnieciskās lietās doc. v. i. L. Jansons;

5) astronomijas prof. A. Žaggers;

6) geofizikas prof. L. Slaucītājs;

7) matemātikas doc. E. Leimanis;

8) geofizikas doc. P. Putniņš;

9) fizikas doc. J. Fridrichsons;

10) Komunistiskās partijas pārstāve, fizikas studente V. Kacena;

11) Komunistiskās jaunatnes savienības pārstāve, fizikas studente H. Krīgere;

12) Studentu profesionālās organizācijas pārstāvis L. Melderis;

13) Valsts Elektrotehniskās fabrikas (VEF) pārstāvis A. Krauklītis;

14) Zemes bagātību pētniecības institūta pārstāvis J. Irbēns;

15) un 16) Jūrniecības pārvaldes pārstāvji A. Pēteris un F. Lende.

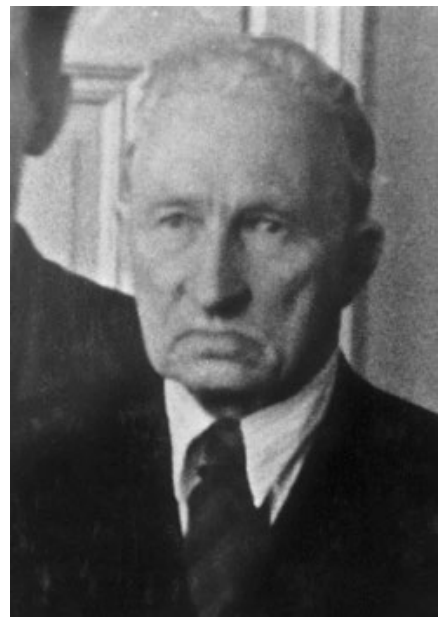

\section{3. attēls. Fizikas un matemātikas fakultātes}

dekāns Pauls Ēks (no 1941. gada 15. februāra līdz 1. jūlijam)

Atbrīvotos vai trūkstošos mācībspēkus centās aizvietot ar uzaicinātiem darbiniekiem no PSRS augstskolām, kuri bija palikuši nerepresēti 30. gadu kadru tīiňšanu akcijās. Fizikas katedrā 15. decembrī pieṇēma bijušo Maskavas Valsts universitātes fizikas doc. Paulu Ëku (3. attēls), kas 1941. gada 15. februārī kḷuva par FMF dekānu F. Gulbja vietā, jo pēdējais uzrakstīja atlūgumu sakarā ar grāmatas rakstǐšanu. No Krievijas Novgorodas rajona kādas skolas 1941. gada janvārī tika komandēta fizikas skolotāja M. Loja, lai papildinātu komunistiski noskan,oto FMF darbinieku skaitu.

Fizikas katedras 1940./41. mācību gada štatu saraksts: katedras vadītājs - prof. F. Gulbis (līdz 15.02.1941., pēc tam P. Ēks), prof. B. Bružs (atbrīvots no LVU 27.02.1941. sakarā ar izceļošanu uz Vāciju), doc. J. Fridrichsons, doc. v. i. A. Apinis, doc. v. i. L. Jansons, stundu doc. R. Siksna, doc. Pāvils Ēks (no 15.02.1941. katedras vadītājs), asist. J. Čudars (no 1.10.1941.), asist. i. Everss, asist. E. Jakobsons, asist. F. Dravnieks, vec. laborante M. Loja (no 27.03.1941.), laboranti F. Meimanis, E. Pūce, K. Bērziņš, M. Taube (no 15.04.1941.), fizikas metodikas lektors J. Ģirupnieks.

FMF mācību plānus pārṇēma no PSRS, bet ar izmaiṇām, kas atbilda vietējām vajadzībām. Mācību ilgumu pagarināja par vienu gadu, 
t. i., līdz pieciem kursiem (studiju gadiem), un pilnībā pārgāja no priekšmetu sistēmas uz kursu sistēmu.

Fakultātē I kursā studēja 63 studenti, II - 58, III - 53, IV - 27, V - 50, t. i., kopā 251 students. Ziemas sesijā FMF pavisam sekmīgi pabeidza 10 studenti, to skaitā fizikas novirzienu - 2 studenti.

Fizikas institūtā zinātniskā darba plānā bija iekḷautas trīs galvenās tēmas: 1) elektroni un fotoni, 2) metālu fizika, 3) kosmiskā radiācija. Rentgenstaru radìto fotoelektronu un izkliedes elektronu ìpašības pētīja doc. J. Fridrichsons. Ar elektronu sadursmju pētijumiem nodarbojās asistents J. Čudars. Docenti R. Siksna un L. Jansons nodarbojās ar atomu spektroskopijas jautājumiem un tehnisko fiziku. Prof. B. Bružs pētīja termodinamikas jautājumus. Metālu fizikā pētījumus veica doc. P. Ēks. Kosmiskās radiācijas pētījumus vadīja prof. F. Gulbis.

1941. gada 22. jūnijā nacistiskās Vācijas karaspēks negaidīti uzbruka PSRS. Padomju karaspēks strauji atkāpās. Latviju steigā atstāja LPSR valdỉba un komunistiski noskaņotie iedzīvotāji. Tiem līdzi aizbēga dekāns P. Ēks un laborante M. Loja. Tika pārtraukta pavasara mācību sesija LVU. Vācieši jau 1. jūlijā ienāca Rīgā. Tajā pašā dienā LU Padomes sēžu zālē sanāca universitātes pagaidu vadības ārkārtējā sēde, kas nolēma atjaunot akadēmisko darbu saskaṇā ar 1923. gadā pieṇemto LU Satversmi.

\section{Vācu nacistu okupācijas laiks (1941-1944)}

Tika likvidēta Fizikas un matemātikas fakultāte, apvienojot to ar Dabas zinātṇu fakultāti un atjaunojot kopējo MDZF, kā tas bija Latvijas brīvvalsts laikā. Par dekānu kḷuva ārk. prof. F. Gulbis, kas tika atjaunots arī FI direktora amatā uz austrumiem aizbēgušā doc. P. Ēka vietā.

Tomēr jaunā okupācijas vara nesteidzās izsniegt aț̣auju LU turpināt mācību darbu. Sākumā ḷāva tikai zinātnisko darbību institūtos. Mācību darba uzsākšanas aizliegšanu pamatoja ar reihsministra A. Rozenberga (starp citu, Rīgas Politehniskā institūta absolventa) 21.07.1941. rīkojumu Ostlandes reihskomisāram H. Lozem, kas liedza igaun,iem, lietuvie- šiem, baltkrieviem un latviešiem universitāšu darbību. Te izpaudās nacistu vēlme pārvācot jauniegūto austrumu teritoriju iedzīvotājus.

Nacisti pieprasīja no institūtiem ziņas par zinātniskiem darbiniekiem, ar kādām speciālām tēmām tie nodarbojas, cik publikāciju tiem ir, ar kuriem vācu profesoriem ir sadarbība attiecīgo tēmu jautājumos. Zinātniski pētnieciskais darbs bija jāpārkārto saskaṇā ar Vācijas interesēm.

Tomēr vāciešiem kḷuva nepieciešams izglītots darbaspēks, jo daudzi speciālisti bija iesaukti Padomju armijā un ebreji tika represēti. L,oti trūka ārstu un tehniski sagatavotu darbinieku, kuri bija vitāli vajadzīgi kara apstākḷıs. Daudzi LU studenti jau bija tuvu studiju beigām.

Rektora v. i. K. Straubergs ar pūlēm dabūja atḷauju darbības atsākšanai tehniskajās un medicīnas fakultātēs. Nacisti nẹ̦āva lietot nosaukumu Latvijas Universitāte, bet nodēvēja to par Universität in Riga vai latviski Universitāte Rīgā, kaut gan aț̣āva lietot agrākos zīmogus. Pa radio 18. novembrī izziņoja, ka universitātē studēt var pieteikties līdz 4 . decembrim, bet beigšanas valsts eksāmeni sāksies pēc 1. decembra.

Universitātes Padome tika atlaista, bet visu politisko un administratīvo atbildību bija jāuzņemas rektoram M. Prīmanim, kas bija atgriezies no Vācijas un pārņēma vadību. K. Straubergs kḷuva par prorektoru studentu lietās.

MZDF lekcijas un praktiskie darbi atsākās 28. novembrī. Šis fakultātes Matemātikas nodaḷā studēt pieteicās ap 50 jaunu reflektantu un mācības turpināja dậa studentu, kas bija sākuši studēt jau agrāk. Studijas risinājās pēc agrākajiem mācību plāniem.

Dekāni: ārk. prof. F. Gulbis 1941./42. un 1942./43. mācību gadā, ārk. prof. K. Ābele 1943./44. mācību gadā līdz 1944. gada jūlijam, doc. E. Leimanis kā dekāna v. i. līdz 1944. gada oktobrim.

Sekretāri: ārk. prof. K. Ābele 1941./42. un 1942./43. mācību gadā, doc. E. Leimanis 1943./44. un 1944./45. mācību gadā līdz 1944. gada oktobrim.

Matemātikas zinātṇu nodaḷas personālais sastāvs 1943./44. mācību gadā:

Matemātikas seminārs: direktors ārk. prof. Arvīds Lūsis, doc. Ernests Fogelis, doc. Emanuēls Grinbergs, priv. doc. Nikolajs Brāz- 


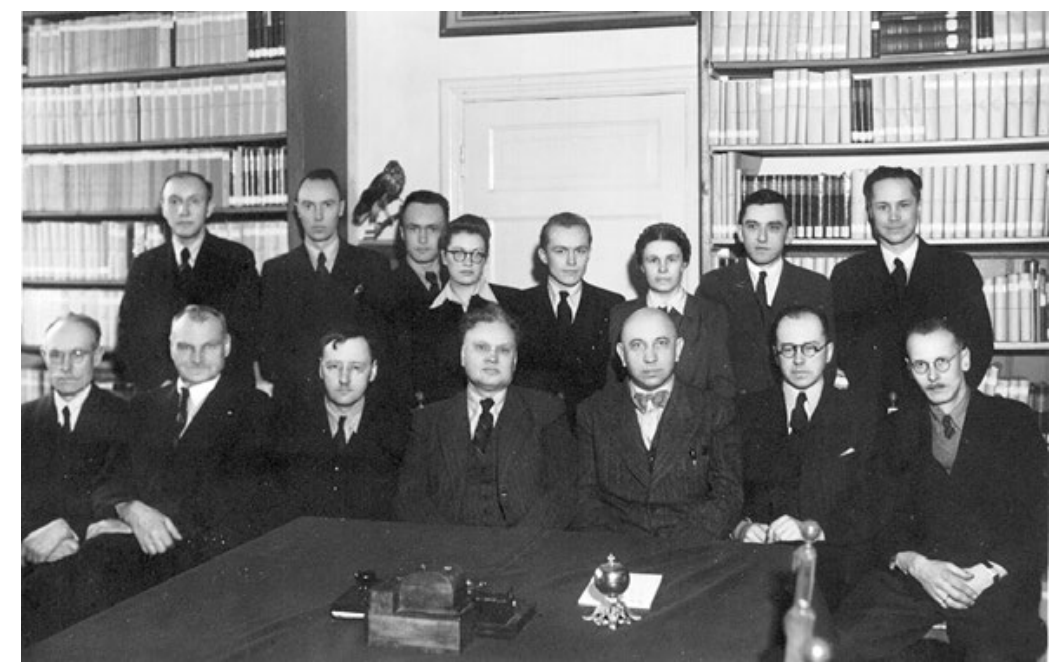

4. attēls. Universitātes Matemātikas un dabas zinātņu fakultātes Matemātikas nodaḷu beigušie ar mācībspēkiem 1944. gada ziemā. No kreisās puses sēž: prof. E. Gēliņš, prof. A. Žaggers, prof.

A. Lūsis, prof. F. Gulbis, dekāns prof. K. Ābele, fakultātes sekretārs doc. E. Leimanis, doc. R. Siksna. Stāv: doc. P. Putniņš, doc. S. Vasiḷevskis, doc. V. Murevskis; beigušie fiziķi: Z. Osvalde-Jurjāne, A. Stravinskis un geofiziķe P. Dlugoborska; pasniedzēji: doc. E. Grinbergs un doc. L. Jansons

ma, asist. Juris Rāts, jaun. asist. Georgs Eṇgelis, jaun. asist. Irīna Auzina.

Fizikas institūts: direktors ārk. prof. Fricis Gulbis, ārštata doc. Jānis Fridrichsons, doc. Reinhards Siksna, doc. Ludvigs Jansons, vec. asistents un lektors Alfons Apinis, asist. Jāzeps Čudars, jaun. asist. Fricis Dravnieks, jaun. asist. Ilmārs Everss.

Teorētiskās astronomijas un analītiskās mehānikas institūts: direktors ārk. prof. Eduards Gēliņ̌̌, doc. Eižens Leimanis.

Astronomiskā observatorija un Laika stacija: direktors ārk. prof. Alfrēds Žaggers, doc. Sergejs Slaucītājs, doc. Staņislavs Vasiḷevskis, ārštata priv. doc. Fricis Blumbahs, asist. Indrikis Brikmanis, asist. Jēkabs Videnieks, asist. v. i. Marija Rozena, jaun. asist. Ilga Kurzemniece.

G̦eofizikas un meteorologiijas institūts: direktors ārk. prof. Leonīds Slaucītājs, doc. Pauls Putniņš, priv. doc. un asist. Valdemārs Murevskis, asist. Andrejs Perechvalıkkis, jaun. asist. Tamāra Ansberga.

Sākoties padomju karaspēka uzbrukumam Rīgai 1944. gada vasarā, liela daḷa MDZF Ma- temātikas nodaļas mācībspēku un studentu pakāpeniski devās bēgḷu gaitās uz Rietumiem vai tika iesaukti Latviešu leǵionā. Vācu nacisti Laboratoriju ēkā Kronvalda bulvārī 4 izvietoja karaspēku. Kādā padomju aviācijas uzlidojuma laikā tika sabombardēts ēkas priekšpuses labā spārna augšējais stāvs un izsistas visas logu rūtis. Rīga krita atkārtotā padomju armijas okupācijā 13. oktobrī.

\section{Fizikas un matemātikas fakultātes pēc- kara atjaunošanas posms (1944-1958)}

1944. gada oktobra otrajā pusē tika atjaunota Latvijas Valsts universitātes vadība, statūti un struktūra, kas bija līdzīga 1940./41. mācỉbu gadā izstrādātai un pieņemtai. FMF Matemātikas nodaļas palikušie darbinieki matemātiķi N. Brāzma, A. Lūsis, E. Fogels, E. Grinbergs, G. Eņgelis; fiziķi: L. Jansons, A. Apinis, J. Čudars, I. Everss un astronoms F. Blumbahs, kā arī palīgpersonāls sāka atjaunot fakultāti. Tās administrācija un matemātiḳi izvietojās sākumā Raiņa bulvārī 19 (6. attēls), 
kopš 1945. gada Baznīcas ielā 5 (7. attēls), bet no 1950. līdz 1958. gadam - Kronvalda bulvārī 4 (1. attēls).

Bijušo institūtu un kabinetu vietā 1944. gada rudenī izveidoja sešas katedras: Vispārīgās matemātikas (vadītāja v. i. doc. N. Brāzma), Matemātiskās analīzes (vadìtāja v. i. A. Lūsis), Eksperimentālās fizikas (vadītāja v. i. L. Jansons), Teorētiskās fizikas (vadītāja v. i. A. Apinis), Ģeofizikas (vadītāja v. i. L. Jansons) un Astronomijas (vadītājs prof. F. Blumbahs). Par fakultātes dekāna v. i. iecēla doc. Nikolaju Brāzmu (5. att., 1944-1947). Pēc vina dekāni tika mainīti šādi: vec. pasn. Ernests Kronbergs (8. att., 1947-1949), doc. Ernests Papēdis (9. att., 1949-1952), doc. Ludvigs Jansons (10. att., 1952-1954), doc. Vilnis Detlovs (11. att., 1954-1956), doc. Elza Kraulina (12. att., 1956-1959).

Atseviškās bibliotēkas, kas atradās attiecīgo zinātṇu nozaru pārvaldībā un telpās, tika apvienotas kopējā FMF bibliotēkā. Cenzūras organizācija Galvenā literatūras pārvalde no bibliotēkas izṇēma l,oti daudz grāmatu, kuras komunistiskā vadība uzskatīja par ideoloǵiski kaitīgām vai mazvērtīgām.

Vislielākie atjaunošanas darbi bija jāveic fiziķiem Laboratoriju ēkā, kur bija bijis Fizikas institūts un atradās fizikas laboratorijas. Tur 1944. gada vasarā tika izvietots vācu karaspēks, kas visu bija pārveidojis savām vajadzībām un nevajadzīgo izmetis.

Palikušie fiziķi doc. L. Jansona vadībā līdz 1. decembrim telpas saveda kārtībā tā, lai varētu uzsākt tiešo darbu. Mācības sākās 1945. gada janvārī Vispārīgā fizikas praktikumā un Speciālajā fizikas praktikumā. Darbojās arī demonstrāciju kabinets pie I klausītavas un mehāniskā darbnīca. Eksperimentālās katedras rīcībā bija 2000 mācību inventāra priekšmetu par 87500 rubliiem. Eksperimentālo zinātnisko darbu praktiski nevarēja strādāt ar tik trūcīgu aprīkojumu.

Eksperimentālās fizikas katedras vadītāja v. i. doc. L. Jansona dzīves laikā (pēkšņi mira 1958. gada 12. maijā) mācību inventārs bija palielināts līdz 4000 priekšmetu 1 milj. 700 tūkst. rubḷu vērtībā, turklāt liela daḷa bija pašu izgatavoti, jo iegādāties jaunu aparatūru bija ḷoti grūti. Tika papildinātas un izveidotas jaunas laboratorijas:
1. Fizikas vispārējais praktikums apkalpoja FMF I un II kursu studentus un citu fakultāšu (Ḳimijas, Biolog̣ijas, Mehānikas un Inženierceltniecības) studentus. Tas sastāvēja no divām laboratorijām. Vienā praktiskās mācības veica mehānikā, molekulārajā un siltuma fizikā, otrajā - elektrībā un optikā. 1957./58. mācību gadā šajā praktikumā strādāja kopsummā 1550 studentu.

2. Fizikas speciālais praktikums padziḷināti apmācīja tikai fizikas specialitātes III kursa studentus.

3. Radiotehnikas praktikums speciāli apmācīja fizikas specialitātes III kursa studentus.

4. Speciālās laboratorijas pavisam bija izveidotas četras:

4.1. Spektroskopijas;

4.2. Fizikālās optikas;

4.3. Dielektriku fizikas;

4.4. Metālu fizikas.

Šajās laboratorijās studenti izstrādāja kursadarbus un diplomdarbus, kā arī darbinieki veica zinātniskos pētījumus. Galvenos zinātniskos virzienus doc. L. Jansons noteica jau 1949. gadā. Tie bija: optiskā spektroskopija un cietvielu fizika, ieklaujot kā apakšnozari pusvadìtāju fiziku. Regulāri notika atbilstoši divi semināri, kuros studenti un darbinieki referēja par jaunumiem un tos apsprieda.

Bez uzskaitītajām laboratorijām Eksperimentālās fizikas katedrā vēl bija Sagatavotava, Demonstrāciju kabinets, Fizikas metodikas kabinets un darbnīcas metāla, koka un stikla apstrādāšanai.

1958. gadā Eksperimentālās fizikas katedrā jau strādāja 22 mācībspēki: 4 docenti, 6 vecākie pasniedzēji un 12 asistenti, kā arī 24 palīgdarbinieki: 9 vecākie laboranti, 8 laboranti, 3 mācību meistari, 2 mehāniḳi, 1 vecākais tehniķis un 1 stikla pūtējs. Katedras vadītāja v. i. (jo nebija komunistu partijas biedrs) doc. L. Jansons jau 1954. gadā lūdza LVU vadību sadalīt Eksperimentālās fizikas katedru vairākās daḷās, jo tā jau tad bija kḷuvusi par lielu un viens cilvēks nevarēja to sekmīgi vadìt bez pārpūles. Taču LVU vadỉba to neṇēma vērā (tikai pēc doc. L. Jansona nāves no katedras nodalīja divas jaunas katedras: Vispārīgās fizikas un Tehniskās fizikas katedru).

Teorētiskās fizikas katedras pedagogiskais darbs un zinātniskā pētniecība notika Teorē- 
5. attēls. Fizikas un matemātikas fakultātes pirmais dekāns pēc kara (1944-1947) doc. Nikolajs Brāzma

6. attēls. Ēkā Raina bulvārī 19 atradās Fizikas un matemātikas fakultāte (1944, 19581994), Matemātikas kabinets (1919-1926), Matemātikas seminārs (1926-1944), Astronomiskā observatorija (no 1922)
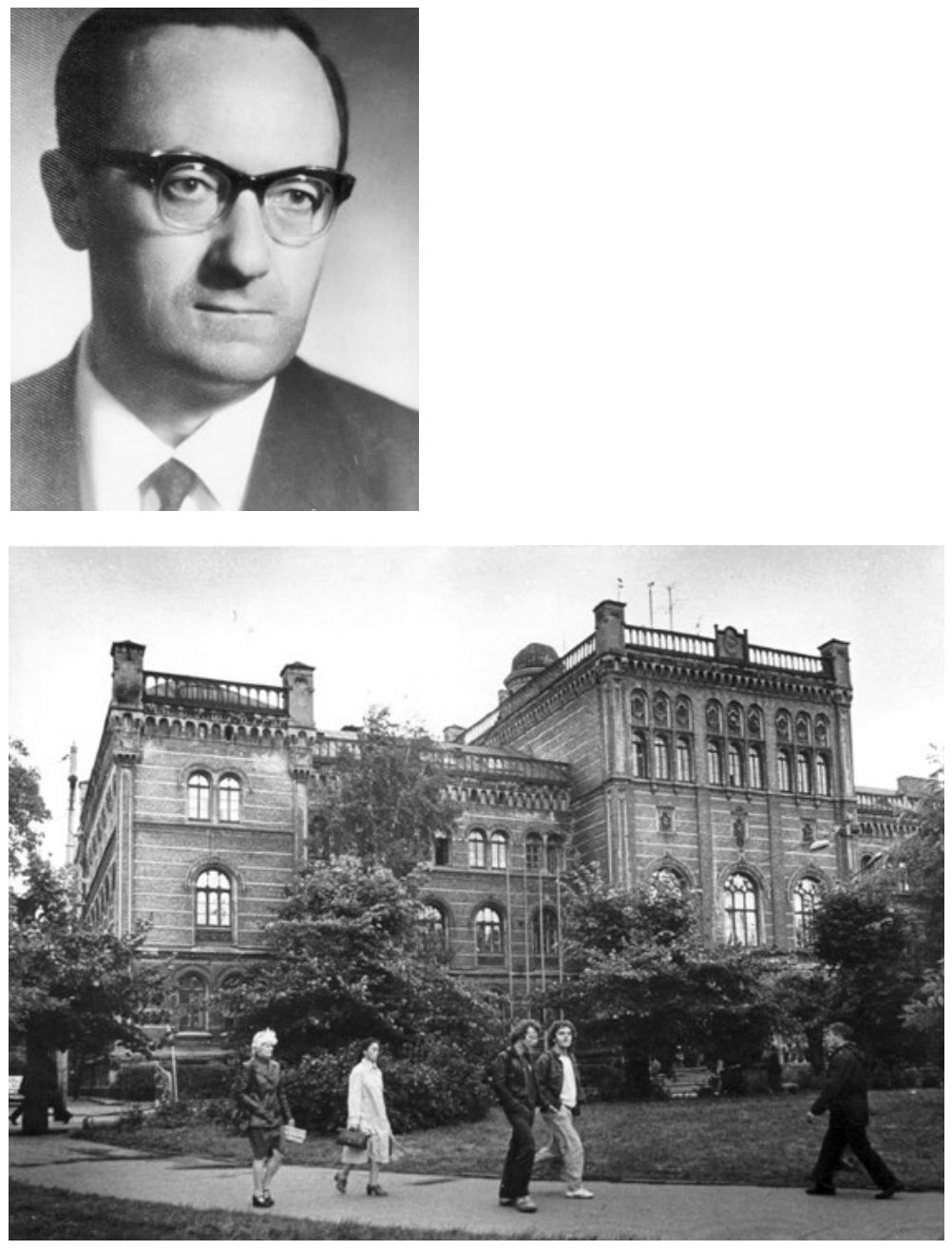

7. attēls. Fizikas un matemātikas fakultātes administrācijas ēka Baznīcas ielā 5 (1945-1950). Teorētiskās astronomijas un analītiskās mehānikas institūts (1925-1941)

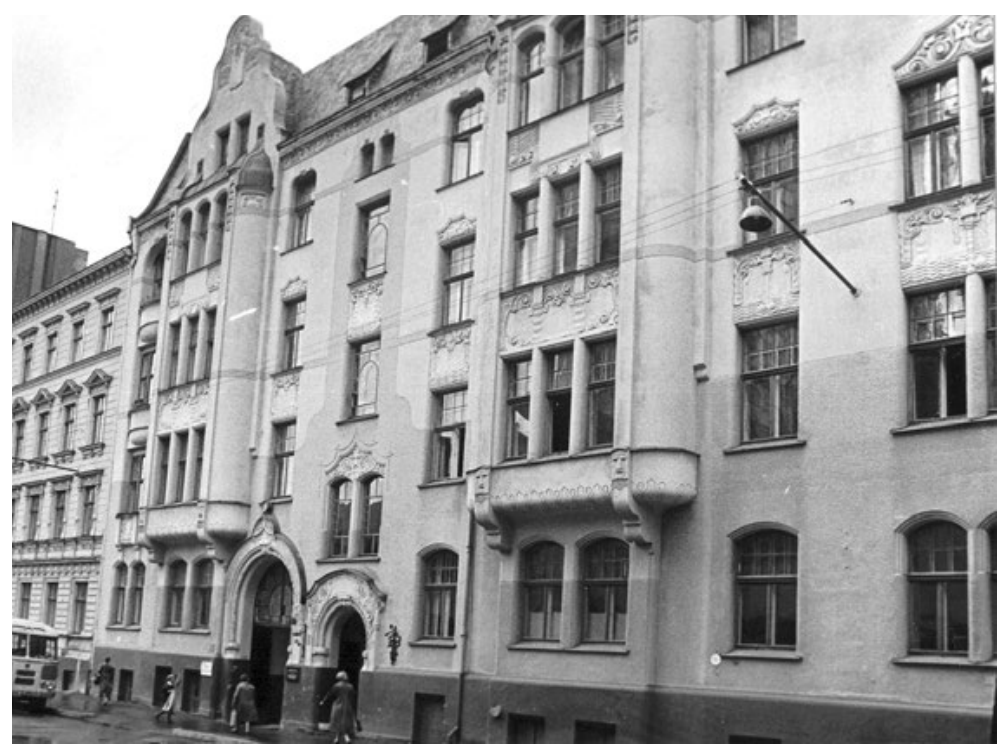


2. tabula. FMF katedras un personāls

\begin{tabular}{|c|c|c|c|c|c|}
\hline Katedras & Profesori & Docenti & Vec. pasn. & Asist. & Kopā \\
\hline Eksperimentālās fizikas & - & 4 & 6 & 12 & 22 \\
\hline Teorētiskās fizikas & - & 2 & 2 & 1 & 5 \\
\hline Vispārīgās matemātikas & - & 2 & 3 & 9 & 14 \\
\hline Matemātiskās analīzes & 1 & 3 & 4 & 1 & 9 \\
\hline Kopā: & 1 & 11 & 15 & 23 & 50 \\
\hline
\end{tabular}

3. tabula. FMF beigušo skaits pa gadiem

\begin{tabular}{ccc}
\hline Gads & Fiziḳi & Matemātiḳi \\
\hline 1945. & 2 & 4 \\
\hline 1946. & 10 & 8 \\
\hline 1947. & 4 & 9 \\
\hline 1948. & 11 & 7 \\
\hline 1949. & 6 & 6 \\
\hline 1950. & 18 & 12 \\
\hline 1951. & 35 & 13 \\
\hline 1952. & 38 & 23 \\
\hline 1953. & 33 & 28 \\
\hline 1954. & 14 & 25 \\
\hline 1955. & 20 & 19 \\
\hline 1956. & 31 & 14 \\
\hline 1957. & 20 & 15 \\
\hline 1958. & 36 & 60 \\
\hline Kopā: & 278 & 243 \\
\hline
\end{tabular}

tiskās fizikas kabinetā. Pakāpeniski iegādājās elektriskos skaitḷotājus. Tas atviegloja aprēķinu veikšanu, kā arī varēja ar tiem apmācīt darboties studentus. 1950. gadā ar PSRS Augstākās izglītības ministrijas lēmumu likvidēja geofizikas un astronomijas specializāciju. Astronomisko observatoriju kopā ar Laika dienestu iekḷāva Teorētiskās fizikas katedrā. Tikai 1958. gadā ar LVU Padomes lēmumu observatoriju nodalīja kā atsevišḳu struktūrvienību fakultātē.

1957. gada rudenī FMF paspārnē doc. V. Šmēlings ar asistentu E. Zablovski izveidoja
Zemes mākslīgo pavadoṇu (ZMP) novērošanas staciju, kas atradās universitātes Botāniskā dārza teritorijā. Pavadoṇu novērošanai tika piesaistīti studenti. ZMP stacija kḷuva par labāko Padomju Savienībā.

1957./58. mācību gadā fakultātē bija 4 katedras un tajās darbojās personāls, kura skaits apkopots 2. tabulā.

Sākot darbu 1944. gada decembrī, studentu skaits fakultātē visos kursos kopā bija apmēram 30. 1945./46. mācību gadā tas pieauga līdz 142, bet 1957./58. mācību gadā jau bija 405 . Beigušo skaits pa gadiem sakārtots 3 . tabulā. 


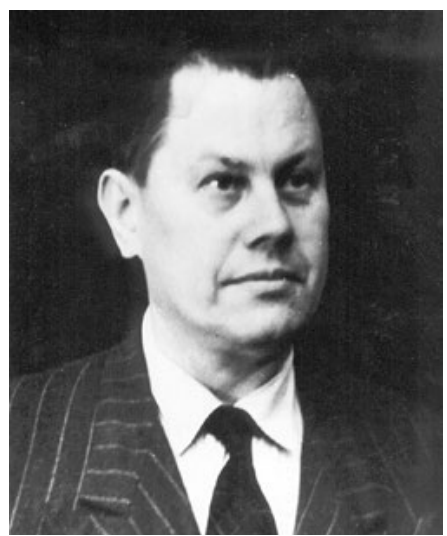

8. attēls. FMF dekāns (1947-1949) vec. pasn. Ernests Kronbergs

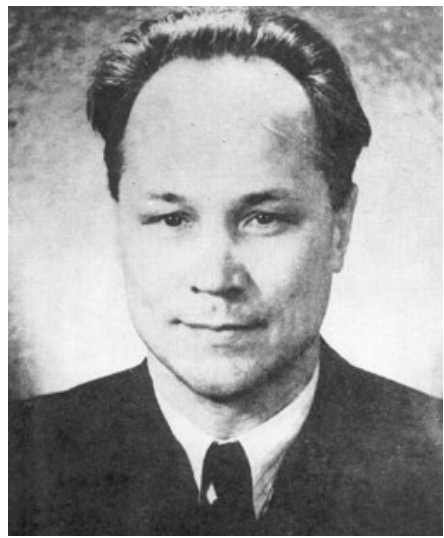

10. attēls. FMF dekāns (1952-1954) doc. Ludvigs Jansons

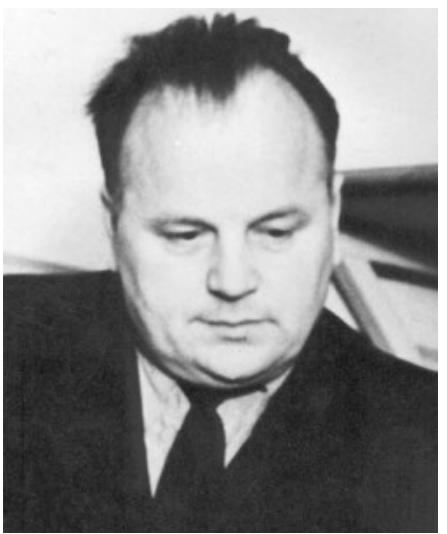

9. attēls. FMF dekāns (1949-1952) doc. Ernests Papēdis

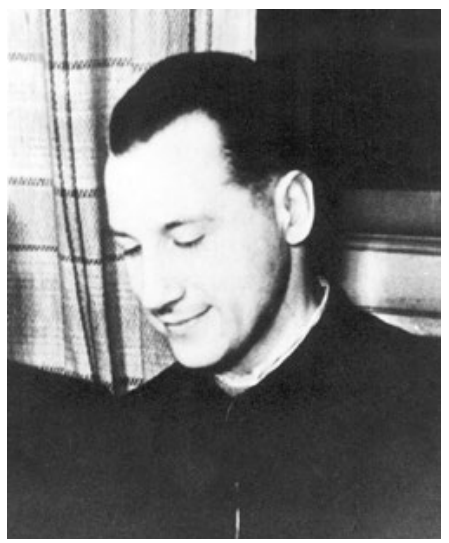

11. attēls. FMF dekāns (1954-1956) Vilnis Detlovs

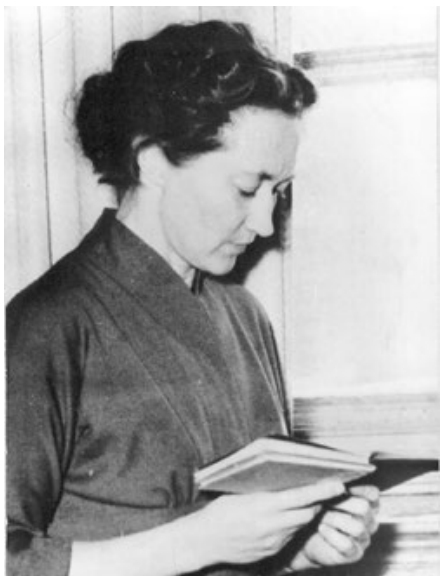

12. attēls. FMF dekāne (1956-1959) doc. Elza Kraulina 


\section{Mācības fakultātē}

Līdz 1948. gadam studijas notika pēc pagaidu plāniem, pakāpeniski pārejot uz PSRS pieṇemtajiem jaunajiem universitāšu mācību plāniem. Tie paredzēja jau no pirmā kursa atdalìt fizikas un matemātikas specializāciju. Fiziķiem augstāko matemātiku mācīja pirmajos divos kursos, bet matemātiskās fizikas metodes - III un IV kursā.

Matemātiķiem matemātikas priekšmetus varēja sakārtot tā, lai tie logiski sekotu cits citam, kas nebija iespējams agrākajā laikā, kad valdīja divu posmu mācības. Ieviesa arī atsevišķus obligātus kursus: variāciju rēḳinus, integrālvienādojumus, reālā mainīgā funkciju teoriju, geometrijas pamatus un matemātikas praktikumu.

Lìdz 1955. gadam matemātikas studenti no 6. semestra specializējās vienā no šādiem virzieniem: diferenciālvienādojumi un integrālvienādojumi vai funkcionālanalìze un funkciju teorija. Lai sagatavotu speciālistus plašākā jomā pēc jaunajiem 1955. gada plāniem, studenti varēja sākt apgūt kursus pēc izvēles vēl arī matemātiskajā loǵikā, elementārajā matemātikā un par elektronu skaitḷošanas mašīnām (datoriem). Vairums priekšmetos seminārus aizvietoja ar praktiskajiem darbiem, lai studentus nodarbībās aktivizētu. Ieviesa arī kursa darbus, kuri bija jāizstrādā un jāaizstāv III un IV kursā. Turklāt IV un V kursā obligāta bija pedagogiskā prakse skolās, kura sagatavoja studentus skolotāju darbam. Agrāk skolotāja kvalifikāciju varēja iegūt tikai pēc studijām, kad bija nostrādāts skolā vismaz viens gads un nolikti pieci eksāmeni dažādās pedagoǵijas nozarēs.

Studentiem pirms valsts eksāmeniem bija jāizstrādā un jāaizstāv diplomdarbs. To izstrādāja desmitajā semestrī un aizstāvēja katedras sēdē. Valsts eksāmeni bija divi: 1) Padomju Savienības Komunistiskās partijas vēsturē un 2) fizikā vai attiecīgi matemātikā.

No visām eksaktajām zinātnēm 20. gadsimta vidū visstraujāk attīstījās fizika. Tamdēl fizikas studentiem nāca klāt arvien jauni mācību priekšmeti un fakti. Tā, piem., eksperimentālās fizikas kurss kopā ar laboratoriju darbiem 1939. gadā aptvēra 520 stundu, bet 1949. gadā jau 1050 stundu. Studenti arvien vairāk specializējās. 1950. gadā fiziḳi tika sagatavoti teorētiskajā fizikā, optikā un cietvielu fizikā. Teorētiḳi papildus apguva nepārtrauktās vides mehāniku, relatīvistisko kvantu mehāniku, kodolu teoriju, elementāro dalịnu teoriju, kvantu elektrodinamiku. Optiksi apguva vēl arī atomu un molekulu spektroskopiju, luminiscenci u. c. izvēles kursus. Cietvielu fiziķi - kristālfiziku, dielektriķu fiziku, pusvadītāju fiziku, metalogrāfiju, metālfiziku, rentgenogrāfiju. Fiziķiem bez pedagogiskās prakses bija arī ražošanas prakse zinātniski pētnieciskos institūtos vai rūpnīcu fizikas laboratorijās. Daudzi studenti diplomdarbu aizsāka izstrādāt ražošanas prakses laikā.

\section{Zinātniskais darbs fakultātē}

Zinātniskais darbs bija l̦oti apgrūtināts, jo 1944. gadā tika likvidēts Fizikas institūts un Matemātikas seminārs. Tā vietā jaundibinātajā Latvijas Zinātṇu akadēmijā 1946. gadā izveidoja Fizikas un matemātikas institūtu, kurā līdztekus LVU strādāja liela daḷa mācībspēku. Tā bija ìpaša komunistu politika - atņemt augstskolām zinātniskā darba iespējas, lai sakoncentrētu nozīmīgos zinātniski pētnieciskos darbus, kas varētu noderēt valsts militāri rūpnieciskām vajadzībām, zinātṇu akadēmiju institūtos vai vēl slēgtākās organizācijās.

Tamdēl no 1945. līdz 1958. gadam LVU tika aizstāvēts l,oti maz fizikas un matemātikas zinātṇu kandidāta disertāciju. Fizikā - 2 (J. Čudars un A. Apinis, bet viṇam Maskavā to neapstiprināja politisku iemeslu dēḷ), matemātikā - 2 (E. Fogels un E. Riekstiņš). Vēl daži aizstāvēja disertācijas citās PSRS augstskolās: fizikā - 2 (E. Krauliṇa un V. Veldre), matemātikā - 3 (E. Āriņš, V. Detlovs un S. Kračkovskis) un astronomijā - 1 (K. Šteins). Bet fizikas un matemātikas doktora disertācija bija aizstāvēta tikai viena - matemātikā (A. Miškis). Turklāt uz iepriekšējo darbu pamata fizikas un matemātikas zinātṇu kandidāta grādu pieškūira bez disertācijas aizstāvēšanas: fizikā - L. Jansonam un matemātikā - N. Brāzmam, bet doktora grādu matemātikā - A. Lūsim.

Par zinātniskā darba rezultātiem var spriest pēc publikāciju skaita pa gadiem (4. tabula).

Zinātniskie pētniecības darbi bija publicēti gan republikas, gan vissavienības, gan arī ārzemju žurnālos. Publicēti arī LVU Zinātnisko 
4. tabula. Publikāciju skaits pa gadiem

\begin{tabular}{|c|c|c|c|c|c|}
\hline Gads & $\begin{array}{l}\text { Eksperimentālās } \\
\text { fizikas katedra }\end{array}$ & $\begin{array}{c}\text { Teorētiskās } \\
\text { fizikas katedra }\end{array}$ & $\begin{array}{c}\text { Vispārīgās } \\
\text { matemātikas } \\
\text { katedra }\end{array}$ & $\begin{array}{c}\text { Matemātiskās } \\
\text { analīzes katedra }\end{array}$ & Kopā \\
\hline 1945. & 3 & - & - & - & 3 \\
\hline 1946. & - & - & - & - & - \\
\hline 1947. & - & - & - & 4 & 4 \\
\hline 1948. & 1 & - & 1 & 5 & 7 \\
\hline 1949. & 1 & - & 3 & 3 & 7 \\
\hline 1950. & - & 2 & 10 & 8 & 20 \\
\hline 1951. & 2 & 3 & 9 & 3 & 17 \\
\hline 1952. & - & 5 & 19 & 5 & 29 \\
\hline 1953. & 2 & 4 & 8 & 6 & 20 \\
\hline 1954. & - & 2 & 7 & 4 & 13 \\
\hline 1955. & 3 & 2 & 5 & 1 & 11 \\
\hline 1956. & 5 & 8 & 12 & 3 & 28 \\
\hline 1957. & 4 & 5 & 2 & 1 & 12 \\
\hline 1958. & 6 & 7 & 7 & 8 & 28 \\
\hline Kopā: & 27 & 38 & 83 & 51 & 199 \\
\hline
\end{tabular}

rakstu 3 sējumos - VI (1952), VIII (1956) un XX (1958).

Fakultātes zinātnieki regulāri piedalījušies ar referātiem dažādas pakāpes konferencēs gan universitātē, gan republikā, gan ārpus tās.

Eksperimentālās fizikas katedrā sākumā nodarbojās ar augstsprieguma stabilizāciju, izmantojot elektronu lampas (L. Jansons), ar gāzu izlādes parādībām un to produktiem (L. Jansons), pētīja katodu izputēšanu (I. Everss), brīvo elektronu sadursmes ar elektronu kūli (J. Čudars), ar atomu spektroskopiju (E. Krauliņa). 1949. gadā L. Jansons, izstudējot zinātnisko literatūru un izvērtējot reālās iespējas, nāca pie secinājuma, ka visperspektīvākā ir nodarbošanās ar fizikālo optiku un cietvielu fiziku, ieskaitot pusvadītājus - nākotnes radioelektronikas pamatu. Šajā izvēlē viņš nebija kḷūdījies. Vēlāk Rīgā tika uzbūvēta Pusvadìtāju rūpnīca, kas ražoja diodes, tranzistorus un mikroshēmas. Šajā rūpnīcā darbvietas atrada daudzi FMF absolventi.

Ar atomu spektroskopiju turpināja nodarboties E. Krauliṇa, molekulu spektroskopiju uzsāka J. Eiduss, kristālu spektroskopiju L. Jansons, O. Šmits, V. Zīraps. Cietvielu fizikā vienkāršākos dielektriķus - jonu kristālus audzēt un pētìt sāka L. Jansons, A. Jansone, O. Šmits, V. Zīraps un K. Švarcs, segnetoelektriķ̧us - V. Fricbergs. Ar metālu īpašîbu pētīšanu nodarbojās P. Ēks, E. Papēdis, V. Fḷorovs, ar rentgenstruktūranalīzi - J. Kručāns. Šajos novirzienos, ieskaitot pusvadītājus, savus diplomdarbus izstrādāja daudzi studenti minēto zinātnieku vadībā.

Teorētiskās fizikas katedrā zinātniskās pētniecības pamatvirzieni bija elementāro dalịnu teorija, ar ko nodarbojās P. Kuṇins un B. Rolovs, teorētiskā spektroskopija - E. Andersons un Z. Tutāne, Saules sistēmas mazie ķermeṇi K. Šteins.

Zinātnisko pētniecību veica arī Astronomiskajā observatorijā un Laika dienestā, kur pamatā nodarbojās ar precīzā laika noteikšanas pētījumiem - E. Kaupužs, L. Roze, J. Klētnieks, K. Šteins, kā arī agrāk līdz 1950. gadam ar maiņzvaigžņu novērojumiem - J. Ikaunieks, A. Briede, A. Mičulis, A. Alksnis. 


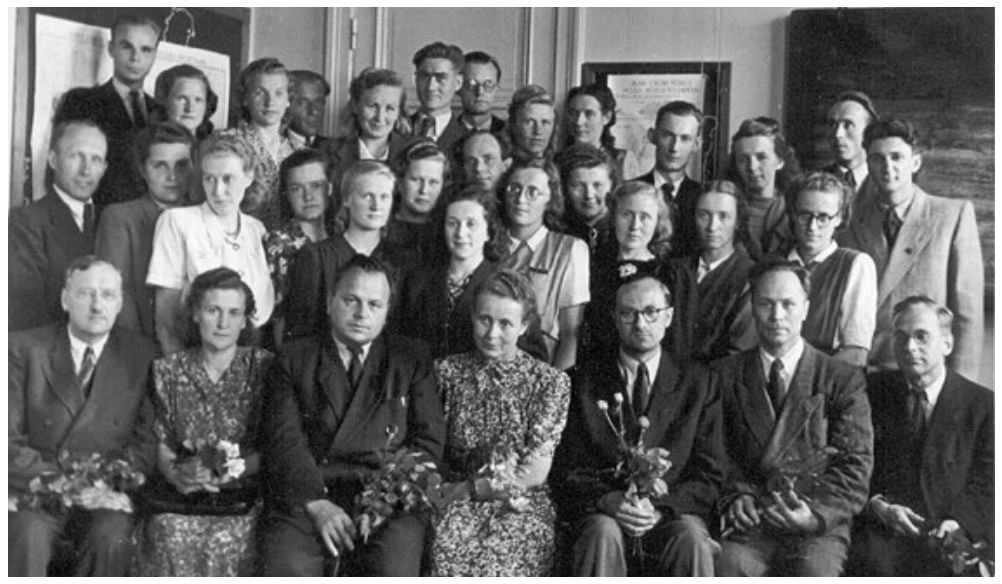

13. attēls. FMF pirmais pilnais izlaidums1949./50. mācību gadā. Sēž no kreisās puses: prof. A. Lūsis, asist. H. Krīgere, dekāns E. Papēdis, vec. pasn. A. Jansone, doc. N. Brāzma, doc. L. Jansons, pasn. G. Enğgelis

Vispārīgās matemātikas katedrā N. Brāzma, A. Miškis, E. Riekstiņš un V. Āboliṇa nodarbojās ar parciāliem diferenciālvienādojumiem un to sistēmām; A. Miškis - diferenciālvienādojumiem ar retardējošiem argumentiem; A. Miškis, E. Lepina un J. Engelsons - ar topolog̣iju; E. Riekstiņš - speciālām funkcijām; E. Riekstiņš un I. Kārkliņ̌̌ - operatoru rēḳiniem; E. Riekstiņš un V. Riekstiṇa - funkciju asimptotiku; A. Miškis, A. Lepins un E. Lepina - ar speciāliem matemātiskās analīzes jautājumiem.

Matemātiskās analīzes katedrā ar skaitḷošanas matemātikas un matemātiskās log̣ikas pētījumiem nodarbojās E. Āriņš, V. Detlovs un B. Grīva; funkcionālo analīzi - S. Kračkovskis un L. Ladiženskis; integrālvienādojumiem A. Lūsis; speciālo funkciju teoriju - G. Eñgelis; ar reālā mainīgā funkciju teoriju - E. Āriņš un M. Zandere.

\section{Metodiskais darbs}

Fizikas un matemātikas fakultātē lielu uzmanību pievērsa metodiskam darbam. Eksperimentālās fizikas katedrā pat bija Metodiskais kabinets, kurā pētīja progresīvākās metodes studentu apmācībai. Tā kā agrākās mācību grāmatas bija aizliegts lietot, tad mācībspēki bija spiesti tulkot padomju mācību grāmatas latviešu valodā (I. Everss, J. Eiduss) vai rakstīt jaunas. Doc. L. Jansons uzrakstīja Fizikas praktikumu (1947), kuru pārstrādāja un paplašināja 1954. gadā.

Lielu darbu mācībspēki veica ar skolēniem un skolotājiem, lai skolas fizikai un matemātikai celtu līmeni un fakultātei piesaistītu jaunus un spējīgus studentus. Fakultāte sadarbojās ar republikas Skolotāju metodisko kabinetu. Tika rīkotas gadskārtējās republikas skolu fizikas olimpiādes (fizikā organizēja A. Jansone un V. Šmēlings) un fakultātes Atvērto durvju dienas.

Fizikas un matemātikas (īpaši diskrētās skaiţ̦ošanas) sasniegumi tika popularizēti presē, radio un televīzijā, kā arī daudzos priekšlasījumos mācību iestādēs, rūpniecības un lauksaimniecíbas uzñēmumos. Tika sarakstītas populārzinātniskas grāmatas, piem., P. Kuṇins un I. Taksars - Elementārās daḷiņas, K. Švarcs - Aukstā gaisma, A. Apinis un L. Jansons - Pusvadìtāji un to izmantošana, U. Grīnfelds un I. Strazdiṇa - Ātrāk par domu, kā arī daudzas tika tulkotas no krievu valodas.

\section{Secinājumi}

Fizikas un matemātikas fakultātes nodalīšana no MDZF bija neizbēgama, jo fizika un matemātika l̦oti strauji attīstījās pagājušajā 
gadsimteņa vidus posmā, salīdzinot ar biologiju, geogrāfiju un geodēziju. Piektā kursa ieviešana būtiski nepalielināja mācību laiku specialitātē, jo daudz laika tika veltīts politisko priekšmetu apgūšanai, militārai apmācībai un pedagogisiskai praksei skolās. Pozitīvi ir jāatzīmē praktisko nodarbību palielināšana, ražošanas prakses un kursa darbu ieviešana. Tas jūtami palīdzēja diplomdarbu izstrādāšanā un pēc LVU beigšanas jaunajam speciālistam sākot patstāvīgās darba gaitas.
Fakultātes mācībspēku neatlaidīgais darbs fizikas un matemātikas popularizēšanā skolās deva to, ka 50. gadu otrā pusē studentu skaits bija desmitkāršojies, salīdzinot ar pirmskara laiku. Fizikas un matemātikas fakultāte, neraugoties uz sarežğìtajiem mācību priekšmetiem, LVU mērogā kḷuva par vienu no spēcīgākajām gan mācībās, gan pašdarbībā, gan arī fiziskajā kultūrā un sportā.

\section{VĒRES}

Latvijas Ūniversitāte 1919-1929 (1929) Rīga : Latvijas Ūniversitāte.

Latvijas Universitate divdesmit gados 1919-1939 (1939) I: Vēsturiskas un statistiskas zinas par Universitati un tās fakultatēm; II: Mācību spēku biografijas un bibliografija. Rīga : Latvijas Universitate.

Leimanis, W.; Slaucītājs, L. (1969) Latvijas Universitātes Matēmatikas un dabas zinātñu fakultātes Matēmatikas zinātnu nodala: Pārskats par bijušo mācības spēku zinātnisko un akadēmisko därbību 1939-1969. Sidneja.

Pētera Stučkas Latvijas Valsts universitāte 40 gados (1919-1959) (1959) Rīga : LVI.

Pētera Stučkas Latvijas Valsts universitātei 50 gadi (1969) Rīga : Zinātne.

Pētera Stučkas Latvijas Valsts universitātei 60 gadi (1984) Rīga : Avots, 1984.

Zinātne tēvzemei divdesmit gados 1918-1938 (1938) Rīga : Latvijas Universitāte, 1938.

Latvijas Valsts arhīvs, 1340. fonds.

Latvijas Valsts vēstures arhīvs, 7427. fonds.

Latvijas Valsts universitātes vēsture 1940-1990 (1999) Rīga : Latvijas Universitāte. 